\title{
SUFU wt Allele
}

National Cancer Institute

\section{Source}

National Cancer Institute. SUFU wt Allele. NCI Thesaurus. Code C97820.

Human SUFU wild-type allele is located in the vicinity of 10q24.32 and is approximately $130 \mathrm{~kb}$ in length. This allele, which encodes suppressor of fused homolog protein, is involved in the negative regulation of both hedgehog signaling and transcription. Mutation of the gene is associated with medulloblastoma. 